\title{
The Influence of Theatre in Rosso's Deposition
}

\author{
MARIE PAULETTE KASKINEN
}

The artistic phenomenon known as Italian mannerism is commonly divided into two stages: an early anti-classical style represented by the works of Rosso Fiorentino, Pontormo and possibly Parmigianino, and a mature or elegant phase represented by the paintings of Bronzino, Salviati and Vasari. The anti-classical phase is often associated with a neurotic state of mind, and the artists of the early cinquecento are seen as an "alienated generation."1

The charge of psychological disturbance has been directed particularly at Rosso, beginning with Vasari's account of his life and continuing up to the present. This charge seems to have some validity, but it has also led to the problem of bias: we are predisposed to think of his work as "neurotic." Rosso's Volterra Deposition of 1521 (Fig. 1) has received the most attention of any of his works, and many scholars have focused on the painting's "disturbed" aspects. Rather than emphasize this one element of Rosso's work, I would like to entertain the notion that there were a variety of other influences on Rosso which go further toward explaining the Deposition, and that when seen in the light of these influences the painting is neither as shocking nor as rebellious as we might think.

First, a point should be made regarding the original placement of the Deposition. The painting was commissioned for the altar of a Franciscan chapel of the True Cross, where it complemented the fresco cycles executed there in the fifteenth century. ${ }^{2}$ One explanation for the fact that the figures in the painting seem to cluster along the edges, as if trying to escape, is that this is a mannerist device related to a sense of claustrophobia and the odd juxtaposition of empty and crowded spaces. Another explanation is that the cross itself is the subject of the painting, in keeping with the intended setting. In this sense, as Hamburgh points out, Rosso's composition is completely appropriate to the setting. ${ }^{3}$ 
58 / Renaissance and Reformation

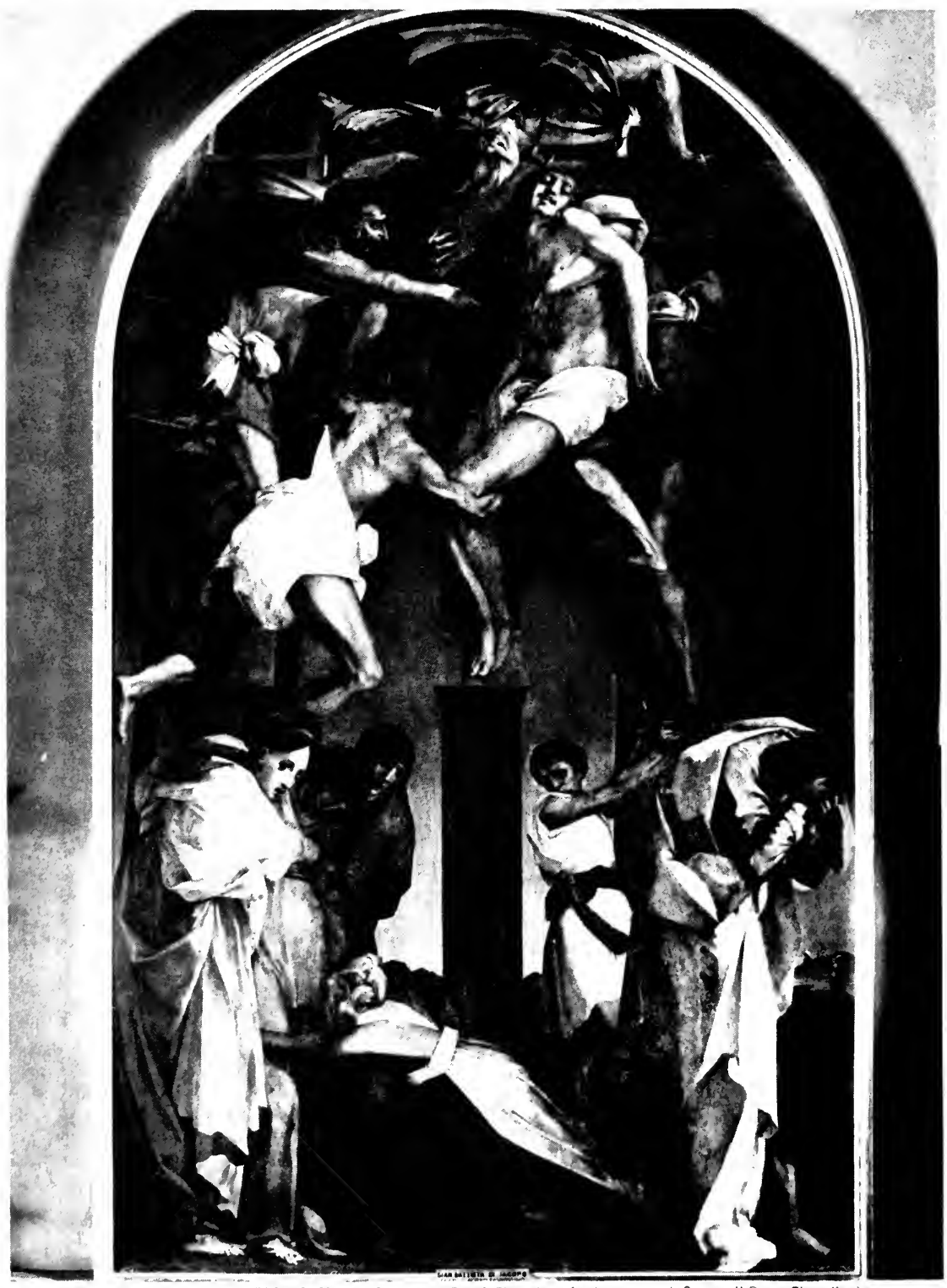

Figure 1: Rosso Fiorentino. Descent from the Cross (Deposition). 1521 Pancl, 11'x 6'" ". Pinacoteca, Volterra. Credit: Alinari/ Art Resource. 
More importantly, the quality of light has been cited to demonstrate Rosso's radical and disturbed rejection of High Renaissance ideals. A harsh, unnatural glare strikes the figures from the right and gives the scene a certain dreamlike quality. In its original location, however, the painting was lit by a window above and to the right, so that the Deposition actually reflected and responded to the light of the chapel. ${ }^{4}$ In other words, the setting itself had a strong influence on the artist in terms of both composition and lighting.

Another possible influence has been mentioned by Eugene Carroll, who points out that in Rosso's The Marriage of the Virgin, painted two years later than the Deposition, the costumes, the setting, the theatrical lighting and the huge crowd of spectators are extremely stagey in comparison to earlier treatments of the subject. ${ }^{5}$ My own research suggests that this theatricality may have its roots in actual religious plays of the cinquecento and can also be seen in some of Rosso's other paintings.

In Renaissance Italy, various types of theatre flourished under the patronage of the nobility. ${ }^{6}$ Performances continued to take place in the streets on many occasions, but the permanent stage was also developing into its modern form. Early in the cinquecento, the stage space was quite shallow despite growing interest in realistic effects of perspective. ${ }^{7}$ Stage designer Sebastiano Serlio described a common practice of locating the front of the stage platform at eye level to the audience; the upstage floor was then constructed with a standard degree of upward slope, so that the actors and scenery were given maximum visibility. ${ }^{8}$

Great attention was paid to the quality and direction of light and to special atmospheric effects. In his seventeenth-century manual for stage design, Nicola Sabbattini advocated a method of lighting scenes predominantly from one side or the other in order to throw dramatic shadows. ${ }^{9}$ To heighten this effect, the scenery itself was painted as if lit from the same side as the actual lighting. ${ }^{10}$

It was also the fashion, since the late quattrocento, to stage exceedingly elaborate religious productions and to concentrate on scenes with complicated engineering problems. ${ }^{11}$ Stage machinery allowed angels to fly across the stage, men to burn in hell, and lightning and thunder to rage quite realistically.

While theatre of the cinquecento often had a mythological content, religious productions also continued throughout Europe. Various types of "tableaux vivants" portrayed biblical scenes in a way that is, in a sense, halfway between painting and theatre. These "show pictures" incorporated living actors into three dimensional scenes within religious street festivals. ${ }^{12}$ 
Each city had its own important festivals: in Florence, the story of the three Magi was acted out each year in the feast of the Epiphany, ${ }^{13}$ and performances are said to have influenced contemporary paintings of the subject. ${ }^{14}$

Productions such as the Florentine Epiphany also fall into the category of "sacre rappresentazioni," religious plays which were characterized by intense naturalism and immediacy. The annual Roman Passion Play was particularly known for its realistic effects: a fifteenth-century eyewitness recorded his impressions of the spectacle and described how even the scourging and the crucifixion were portrayed on stage. ${ }^{15}$ Since artists of the time were attempting to portray on canvas the same scenes played out on stage, it seems likely that these performances often inspired the artists. ${ }^{16}$

A definite link between painting and theatre can be established in the area of sets and costumes. Mantegna, for instance, is said to have been involved in theatrical design, theatre being the favorite entertainment of his patrons, the Gonzagas. ${ }^{17}$ Raphacl is known to have designed scenery for a comedy production for Leo $\mathrm{X},{ }^{18}$ while Vasari, Primaticchio, and Filippino Lippi designed theatrical costumes, ${ }^{19}$ as did Rosso himself, although not until the 1530's when he was at Fontainebleau. ${ }^{20}$

Clearly there was a flow of artistic work from painting to theatre; there was no doubt a corresponding flow from theatre to painting. Weisz repeatedly points out the theatrical quality of the sixteenth-century frescoes at the oratory of S. Giovanni Decollato in Rome, ${ }^{21}$ and ties between the arts may have been particularly strong in Florence where artists and writers from various professions seem to have known one another. ${ }^{22}$ Costume historians have noted instances of dress in paintings being derived from theatrical costumes, ${ }^{23}$ and in at least two cases entire paintings are thought to depict theatrical performances. In a miniature painting, Jean Fouquet recorded a performance of the Martyrdom of St. Apollonia (Fig. 2); the four figures in the foreground hold a cartouche which advertises the mystery play about to be performed, while in the background the placement of seats for the audience is further evidence that the painting portrays an actual theatrical event. ${ }^{24}$ In fact, this painting has been an important source of information in studies of medieval theatre.

The angel choir in Botticelli's Mystical Nativity (Fig. 3), dated 1501, has been traced to the machinery created by Brunelleschi to stage the miracle of the Annunciation at a Florentine church. ${ }^{25}$ This motif of the angels holding hands beneath the dome of heaven corresponds to Vasari's description of Brunelleschi's invention. In northern Europe a similar exchange of ideas seems to have taken place, as demonstrated by the 


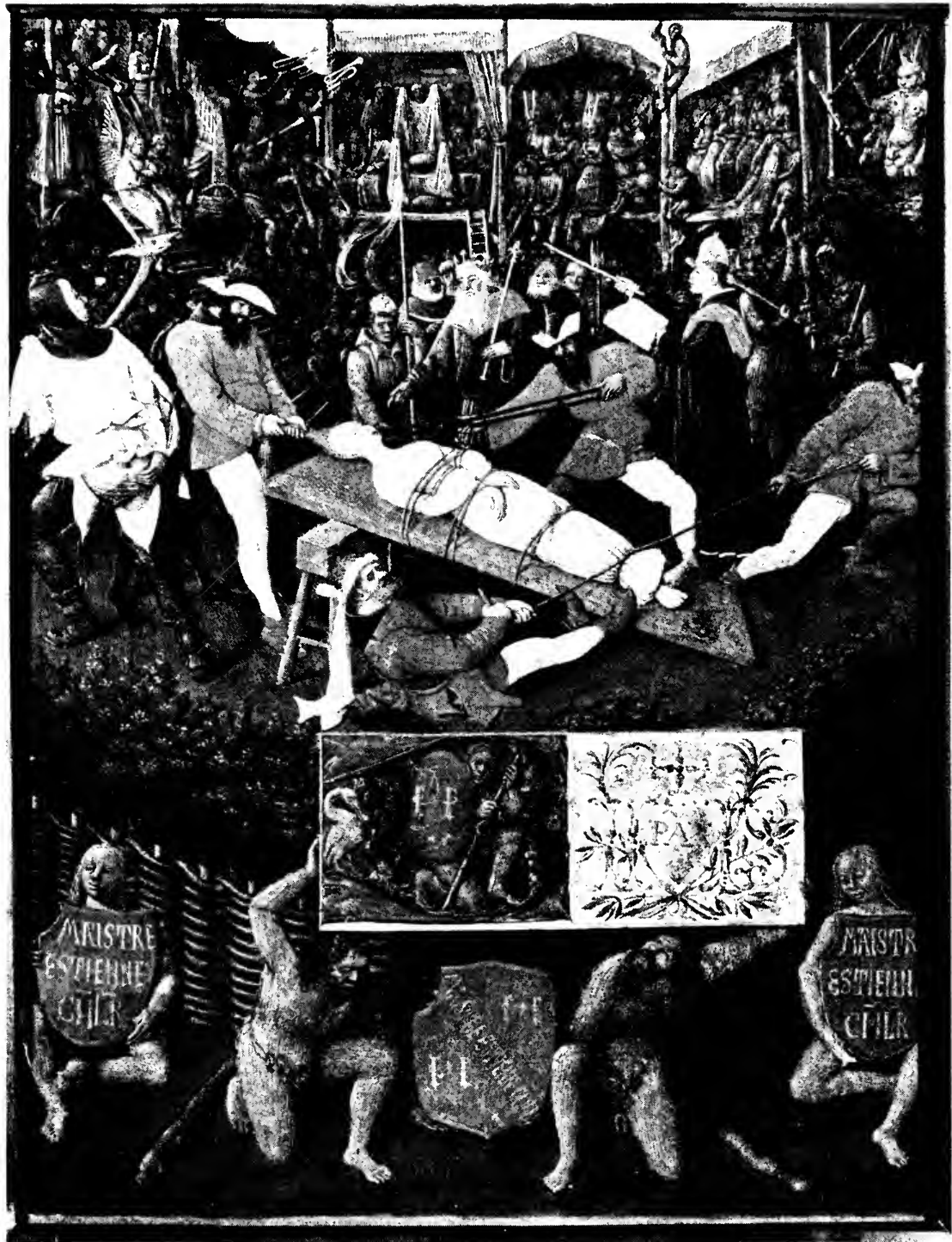

Figure 2: Jean Fouquet. Martyrdom of St. Apollonia.

From The Hours of Etienne Chevalier 1452-56. Musée Condé, Chantilly. Credit: Giraudon/Art Resource. 
62 / Renaissance and Reformation

HYNILVE

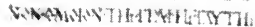

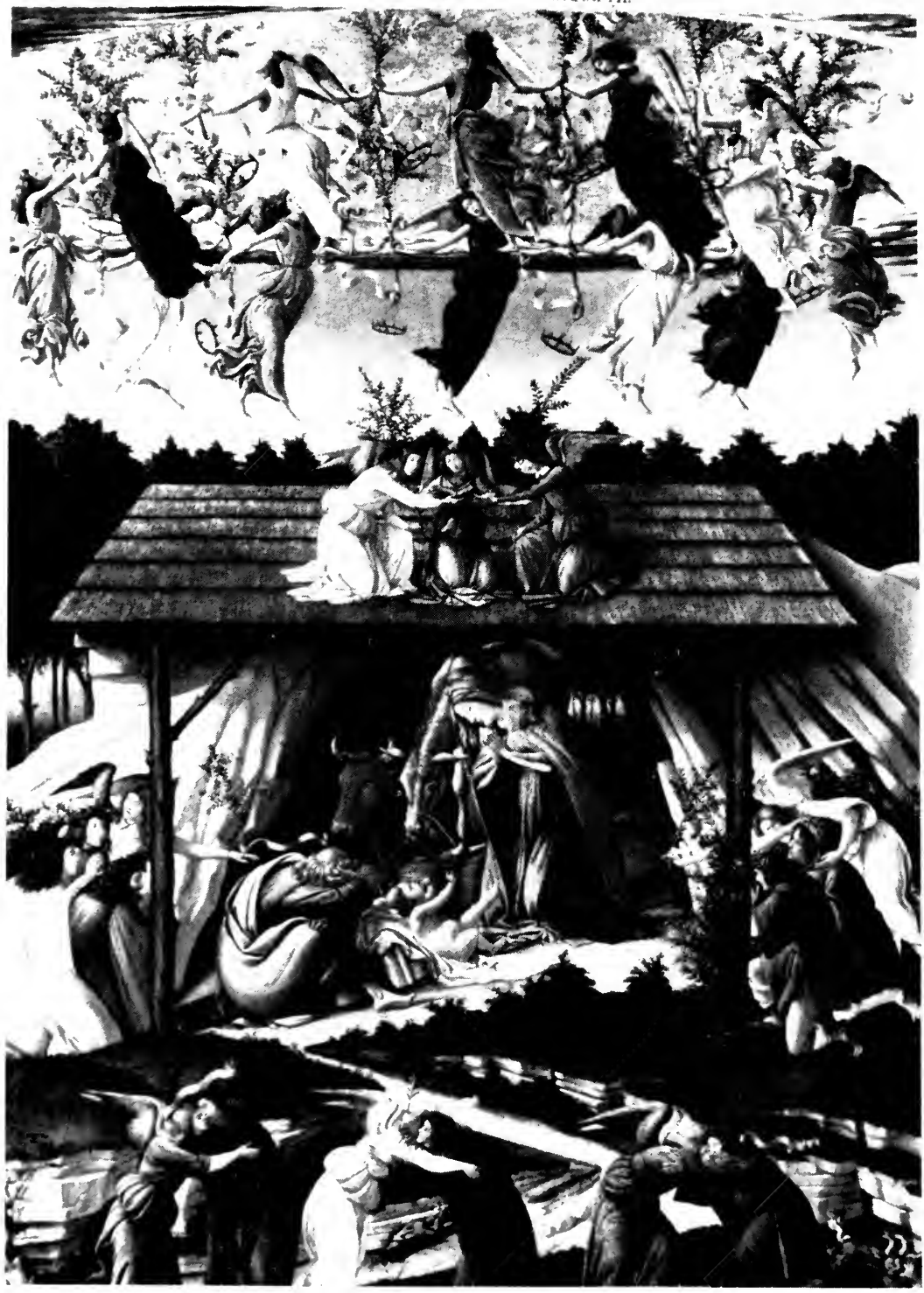

Figure 3: Sandro Botticelli. Mystic Nativity. 1500. Canvas, 43 3/4" x 29 1/2". National Gallery, London. Reproduced by courtesy of the Trustees, The National Gallery, London. 
Annunciation scene in Grunewald's Isenheim Altarpiece (Fig. 4); the curtains behind the Virgin are thought to refer to medieval dramatizations of the event. ${ }^{26}$

Jacopo Pontormo, with whom Rosso was associated in the second decade of the cinquecento, may also have been strongly influenced by the theatre. Cooper has argued that the fresco identified by Vasari as Vertumnus and Pomona, at Poggio a Caiano, "was inspired by The Two Friendly Rivals of Jacopo Nardi and is in fact a memorial to Leo's brother, Giuliano (de' Medici)." 27 There is also solid evidence that both Pontormo and Rosso were directly involved in theatre during the early period when the Deposition was painted. In 1515, the city of Florence was decorated for the visit of Pope Leo X; wooden triumphal arches were stuccoed and painted all along the procession route, and Rosso and Pontormo were among the artists who helped decorate these outdoor props. ${ }^{28}$

At any rate, direct involvement would not have been necessary for Rosso to have been influenced by theatre. Even if he did not actively seek out and attend performances, he could hardly have failed to notice the theatrical events in the streets of Florence. The main evidence for a theatrical influence is in Rosso's paintings themselves, beginning with The Assumption of the Virgin (Fig. 5) of about 1517.

We have seen that Botticelli used the theatrical motif of the angel choir in his Mystical Nativity, and Rosso picked up the same motif in his painting: the ring of angels holding hands does not seem to have any other precedent in painting. ${ }^{29}$ Rosso also introduced another motif which lacks an exact precedent and which could easily have been derived from theatre: he made the "bold" move of letting the drapery of one of the apostles extend over the frame. ${ }^{30}$ This has been seen as one of Rosso's attempts at rebellion, because such a device would not ordinarily have occurred in a High Renaissance painting, ${ }^{31}$ but the idea of a theatrical origin seems just as likely. The effect is not of drapery falling over a frame; the center apostle is standing further forward than the other figures, and the extension of his robe suggests the existence of an edge at the picture plane, just as the lip of the stage runs along the "picture plane" of the proscenium.

Rosso repeats this motif in the Deposition, but here the reference to theatre seems much more emphatic. A "lip" is clearly visible running along the bottom of the painting, and not only the robe of the St. John figure extends past the picture plane: the toes of the Virgin are actually bent down over this edge, establishing the edge as having solidity and flatness in a scene which supposedly takes place on a hill outside the city. 
64 / Renaissance and Reformation

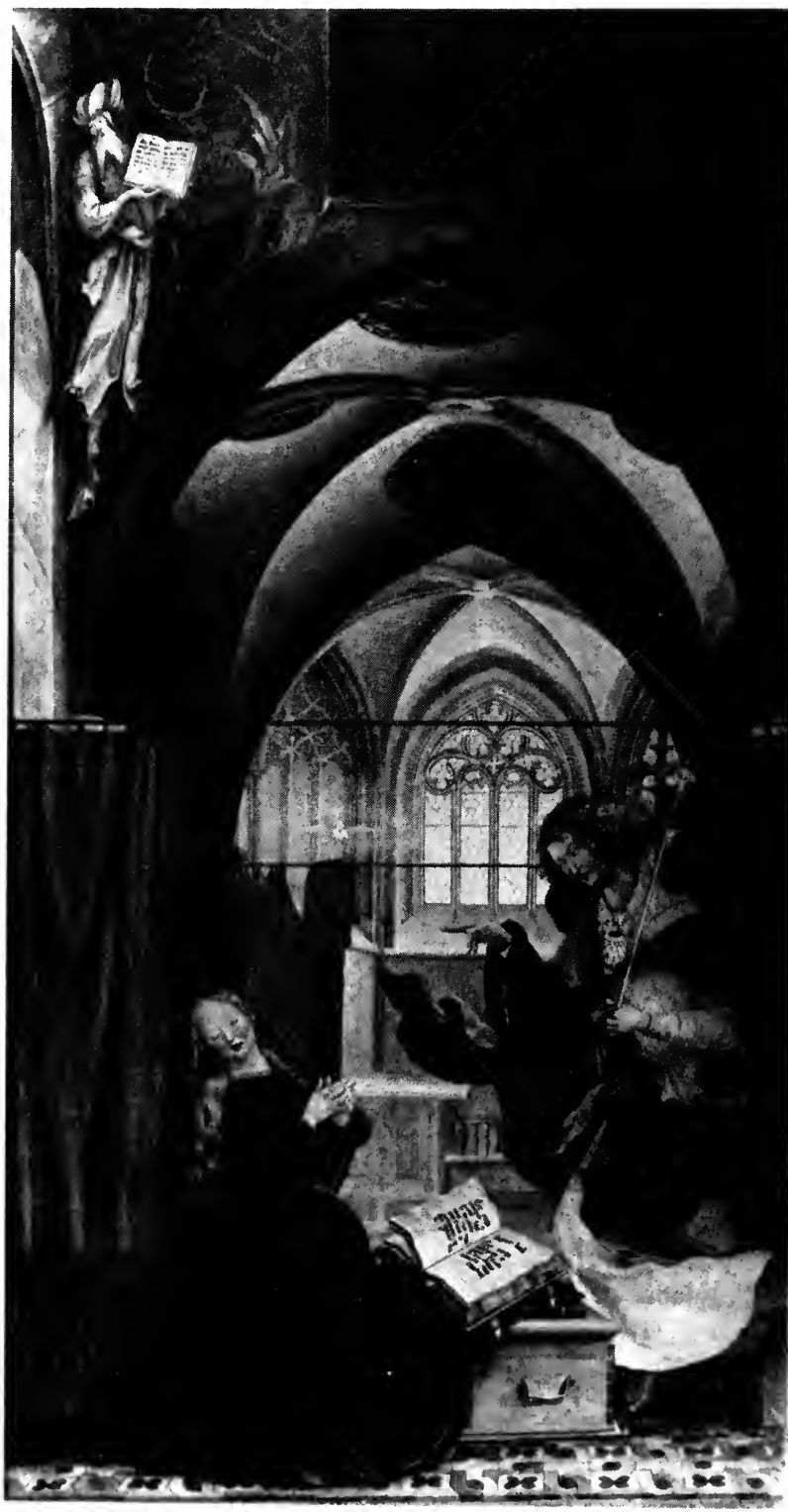

Figure 4: Matthias Grünewald. Annunciation. From the Isenheim Altar. 1513-15.

Unterlinden Muscum, Colmar. Credit: Marburg/Art Resource. 


\section{Renaissance et Réforme / 65}

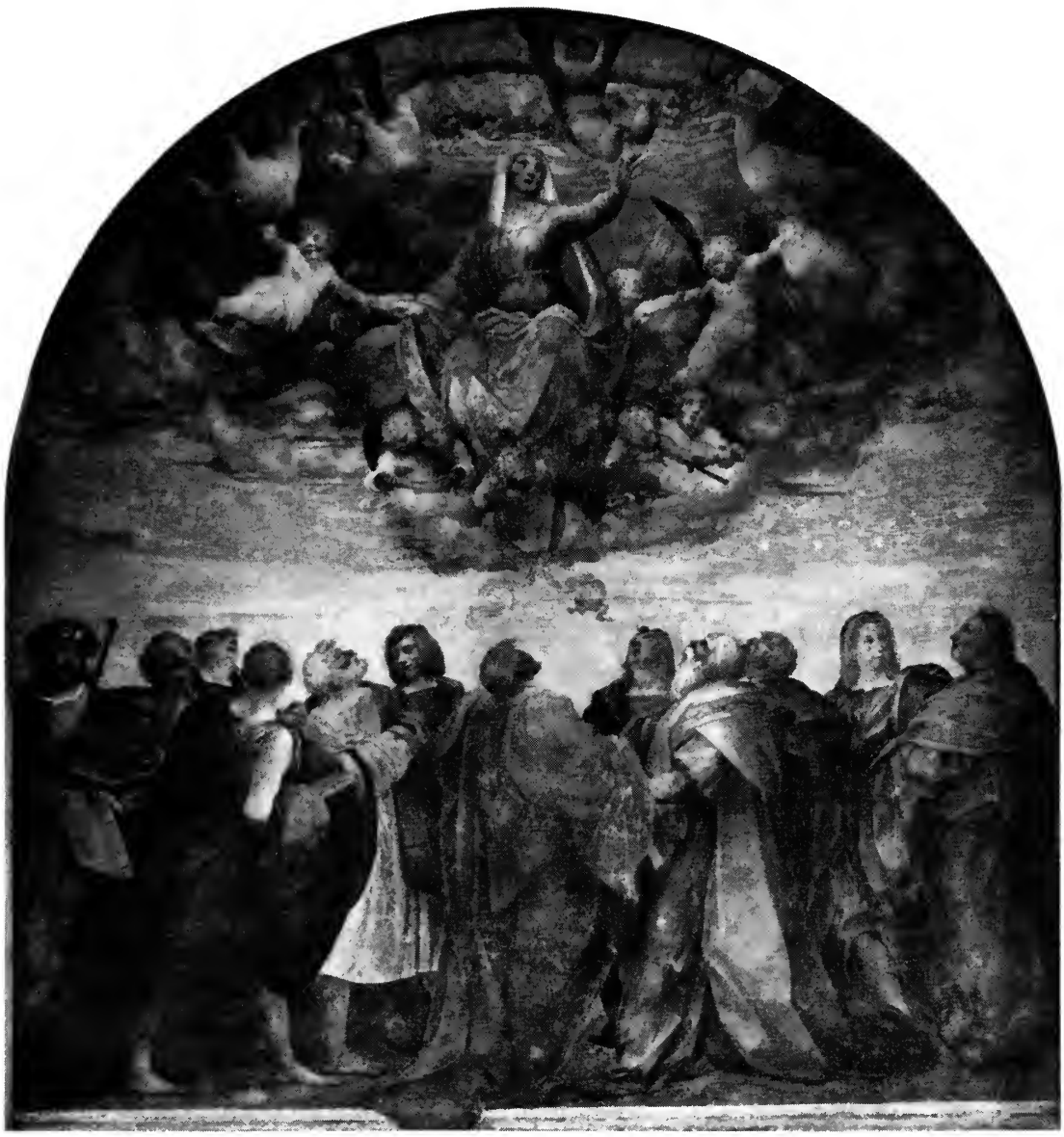

Figure 5: Rosso Fiorentino. Assumption of the Virgin. 1517.

Fresco. Atrium, SS. Annunziata, Florence.

Credit: Alinari/Art Resource. 
Besides this solid horizontal edge, there is a solid vertical at the left side. The St. John figure at the right is cropped and the implied space extends beyond the picture frame, while at the left, this extension of space is blocked: the figure on the ladder rests his foot on a physical edge, giving the effect of action taking place within a physical frame such as the space on a stage.

The space in the painting is shallow, and the background landscape, containing only a few tiny figures at the right, appears almost as a backdrop. The figures are set very close together in the foreground, and the ground itself seems to be tilted up toward the back: the ladder at the right, for instance, is very close behind the figure of St. John, yet it rests at a higher level, suggesting a raked platform not unlike that described by Serlio.

Rosso's use of light has been discussed perhaps more than any other element of the painting, and its harshness has been described as suggesting lightning ${ }^{32}$ further, the lighting is often used as evidence of Rosso's radical rejection of High Renaissance ideals. Yet we have seen that in its original location the painting would have been lit primarily from the right, as is the scene within the painting. In other words, the combination of light within the painting and in the physical setting would have exactly corresponded to Sabbattini's description of ideal stage lighting.

Iconographically, too, the Deposition suggests a theatrical influence. St. John figures depicted with red hair are generally significant in Rosso's work and are often thought of as self-portraits. Here, St. John the Evangelist is shown with red hair and much larger than any of the other figures, and his position in the painting is dominant despite his bent-over posture. All of the other figures face in toward each other, but St. John turns away from the group and partially toward the viewer, bringing to mind theatrical figures such as narrators, which act as intermediaries between the audience and the action on stage. This is entirely in keeping with the subject matter, since it is only in the Gospel of St. John that the Virgin is actually present at the cross. It was to John that Christ entrusted the care of Mary, and Rosso further emphasizes the importance of John and the Virgin with the unusual motif of the leftward thrust of the Magdalen, whose brightly lit form visually connects the grief-stricken pair bending toward the right. In Franciscan theology, "the sacrifice on Calvary is the moment of the emergence of the Church," 33 and thus Rosso appropriately devotes the foreground of the painting to Mary, identified with the Church, the Magdalen, to whom Christ would first appear after the Resurrection, and St. John, the teller of the story.

The general idea of a theatrical influence on Rosso's paintings should not be any more difficult to accept than the idea that the artist was 
emotionally unstable and deliberately included these odd and unprecedented elements to confound his patrons. While there is some evidence that his Madonna and Child with Saints was rejected by the patron who commissioned it, ${ }^{34}$ there is no indication that there was any such problem with the Deposition, and he evidently did not lack for commissions at any point in his career. His work must have been more comprehensible to his patrons than it has been to us; to examine this further, we need to look at the theoretical appropriateness of a theatrical influence on mannerist painters.

To avoid conflicts as to the meaning of "mannerism," I have used the concise definition offered by James Mirollo in his discussion of Renaissance literature: "Mannerist theory is perhaps best explained as the product of a ripe Renaissance culture turning in on and exhaustively exploiting itself." 35

The appeal of such painters as Bronzino and Parmigianino, as well as Pontormo and Rosso, has been explained as a rarefied taste which was confined to the intellectual upper classes who were the main patrons of mannerism. The inclusion of obscure literary, mythological and artistic references, particularly notable in the work of Bronzino, suggests a taste for convolution, for complexity for its own sake. Artists seemed to be commenting on art while they were producing art; the references to poetry, other paintings, and sculpture are well documented throughout the mannerist period. Referring to yet another form of art, the theatre, is precisely the type of intellectual game which would have appealed to the intelligentsia. The mannerist painters deliberately avoided turning to nature for inspiration, but to turn to the theatre was the height of their cleverness: the figures on stage were human, yet the mannerist painter could use them for inspiration since they were real only in the context of the illusion of theatre. Artists could turn to the visual impressions of theatrical performances in much the same way that they turned to the visual impressions of sculpture.

A theatrical model would have been particularly appropriate in the case of Rosso's Deposition. A display of intense emotion was called for, and despite the rather frozen quality of the figures this show of emotion was certainly achieved. The violence of this emotional expressiveness has been seen as Rosso's attempt to evoke in the viewer the same grief which was felt by those who actually witnessed the scene. ${ }^{36}$ If this was Rosso's intent, then he could not have chosen a better model than a live performance of the scene from a passion play.

This paper was intended as a suggestion for further research in the area of theatrical influences in mannerist art. The clothing in certain paintings could, for instance, be traced to see whether it was derived from theatre or 
simply from conventions of dress in painting. More detailed information about theatrical practices of the time and about the relationships between artists would also be helpful. It is certain that the theatre influenced mannerist painting at least indirectly, in the sense that an artist's complete environment influences his work.

\section{University of Virginia}

\section{Notes}

The author wishes to thank Dr. Eugene Carroll, Dr. Asher Wilson, Mr. Louis Maxfield, and especially Dr. Jane Kristof for their advice and encouragement in the development of this paper.

1 Peter Burke, The Italian Renaissance: Culture and Society in Italy (Princeton: Princeton University Press, 1986), p. 236.

2 Graham Smith, "On the Original Location of Rosso Fiorentino's Descent from the Cross," Zeitschrift für Kunstgeschichte 39 (1976): 70.

3 Harvey E. Hamburgh, "Rosso Fiorentino's Descent from the Cross in a Franciscan Context," Sixteenth Century Journal 19 (1988): 580.

4 Smith, p. 70.

5 Eugene Carroll, letter to the author, February 22, 1989.

6 E. R. Chamberlin, The World of the Italian Renaissance (London: George Allen and Unwin Ltd., 1982), p. 276.

7 Barnard Hewitt, ed., The Renaissance Stage: Documents of Serlio, Sabbattini and Furttenbach (Coral Gables: University of Miami Press, 1958), p. 9.

8 Hewitt, p. 25.

9 Hewitt, p. 16.

10 Hewitt, p. 61.

11 Stella Mary Newton, Renaissance Theatre Costume and the Sense of the Historic Past (London: Rapp and Whiting Ltd., 1975), pp. 50-51.

12 George R. Kernodle, From Art to Theatre (Chicago: University of Chicago Press, 1944), p. 52.

13 Burke, p. 207.

14 Roberta J. M. Olson, "Brunelleschi's Machines of Paradise and Botticelli's Mystical Nativity," Gazette des Beaux-Arts 92 (1981): 183.

15 Burke, p. 207.

16 Olson, p. 183.

17 Newton, p. 31.

18 Newton, p. 60.

19 Martin Wackernagel, The World of the Florentine Renaissance Artist (1938; Princeton: Princeton University Press, 1981), pp. 196-197. See also Newton, p. 207.

20 Eugene Carroll, Rosso Fiorentino: Drawings, Prints, Decorative Arts (Washington D.C.: National Gallery of Art, 1987), p. 212.

21 Jean S. Weisz, Pittura e Misericordia: The Oratory of S. Giovanni Decollato in Rome (Ann Arbor: UMI Research Press, 1984), pp. 26-29, 48-49.

22 Burke, p. 218.

23 Newton, p. 33. 
24 James Snyder, Northern Renaissance Ant (New York: Abrams, 1985), p. 246.

25 Olson, p. 183.

26 Georg Scheja, The Isenheim Altarpiece (New York: Abrams, 1969), p. 34.

27 Frederick A. Cooper, "Jacopo Pontormo and Influences from the Renaissance Theater," The Ant Bulletin 55 (1973): 391.

28 Wackernagel, p. 198.

29 Olson, p. 188.

30 Walter Friedlaender, Mannerism and Anti-Mannerism in Italian Painting (New York: Schocken Books, 1957), p. 29.

31 For a rare quattrocento example of a related motif, see Melozzo da Forli, Sixtus IV Appointing Platina. 1474-77. Fresco, transferred to canvas. Pinacoteca, Vatican, Rome.

32 Linda Murray, The Late Renaissance and Mannerism (New York: Praeger Publishers, 1967) p. 54.

33 Hamburgh, p. 586.

34 Giorgio Vasari, The Lives of Seventy of the Most Eminent Painters, Sculptors, and Architects, ed. E. H. and E. W. Blashfield and A. A. Hopkins (New York: Scribner's, 1923), p. 1097.

35 James V. Mirollo, Mannerism and Renaissance Poetry: Concept, Mode, Inner Design (New Haven: Yale University Press, 1984), p. 25.

36 Murray, p. 54. 